\title{
Esch. coli endocarditis successfully treated with oral trimethoprim and sulphamethoxazole
}

\author{
A. S. E. Fowle and P. A. Zorab \\ From Clinical Research Division, Wellcome Research Laboratories, Beckenham, Kent, \\ and St. Mary's Hospital, London W.9
}

A 42-year-old patient was successfully treated for subacute bacterial endocarditis due to Esch. coli with oral trimethoprim and sulphamethoxazole. The treatment lasted nine months and was continued through a period of cholestatic jaundice superimposed on hepatic damage due to subacute bacterial endocarditis. There were no toxic effects attributable to the two antibacterials despite their prolonged administration.

Treatment of subacute bacterial endocarditis is never easy, and treatment with oral drugs causes even greater concern than treatment with drugs by injection. We report here the successful treatment of a case with an oral drug combination not previously used for subacute bacterial endocarditis and for which the components were individually not usually bactericidal. The drugs, trimethoprim and sulphamethoxazole, were used when in vitro testing had indicated that in combination they would be bactericidal to the infecting organism, Esch. coli, against which all other antibiotics had proved ineffective.

\section{Case report}

A cardiac murmur was noted at the age of II in this patient. The diagnosis made at that time is not known, but she had a normal exercise tolerance until a few months before her latest illness. She had normal pregnancies at 25 and 29 years. In July 1967 when 42 years old she had a third normal pregnancy ending in a stillbirth due to strangulation by the cord. Cystitis occurred post partum but seemed to respond to nitrofurantoin. No bacteriological details are available. Lochial discharge persisted for six weeks. Apathy, weakness, and anorexia appeared soon after the birth and gradually increased over two to three months. Then the left fingers, hand, and forearm became tender and swollen. The condition lasted for two weeks and was punctuated by cramp-like pains which settled spontaneously.

One week later, in October 1967 an ache in the left calf, aggravated by exercise, brought her to hospital. On 2 I October pyrexia $\left(38.9^{\circ} \mathrm{C}\right.$.), anae- mia, raised blood sedimentation rate, hepatosplenomegaly, and diminished pulsations in the left radial and dorsalis pedis arteries suggested subacute bacterial endocarditis. She was admitted forthwith. The apex beat was of a hyperkinetic left ventricular character. A thrill and pansystolic murmur maximal at the mitral area were present. The characteristics of an additional ejection systolic murmur were obscured by the murmur due to mitral incompetence.

Investigations The chest $x$-ray was normal except for a small healed apical tuberculous focus. The size of the heart shadow was normal.

Haemoglobin $7.9 \mathrm{~g} . / 100 \mathrm{ml}$; red blood cells 3.3 million, with reticulocytes 3.8 per cent; white blood cells $16,900 / \mathrm{cu}$. mm., with 25 per cent neutrophils; erythrocyte sedimentation rate (Westergren) $87 \mathrm{~mm}$./hr., serum vitamin $\mathrm{Br2}$ 5 Io $\mu \mu \mathrm{g} . / \mathrm{ml}$., serum folate (L.casei) I $\mu \mathrm{mg} . / \mathrm{ml}$. A bone-marrow smear showed normoblastic erythropoiesis and a well-defined plasma cell hyperplasia of reactive type. Bacterial culture was negative. The picture was consistent with an acute systemic infection. Six blood cultures all grew Esch. coli sensitive to streptomycin, chloramphenicol, tetracycline, ampicillin, kanamycin, and cephaloridine and nalidixic acid.

The unexpectedly low serum folate level in the absence of antibacterial treatment though associated with anaemia prompted fuller investigations of liver function than is usual but they only showed minor abnormalities consistent with subacute bacterial endocarditis.

Treatment began with $\mathrm{I} \cdot \mathrm{O}$ g. ampicillin intramuscularly, but within 20 minutes this caused vomiting, diarrhoea, and hypotension requiring immediate treatment with adrenaline. Cephalori- 
dine 1.0 g. b.d. was, therefore, substituted. At the end of a week the pyrexia had not settled so streptomycin, $\mathbf{I} \circ \mathrm{g}$. intramuscularly daily, was added. Creatinine clearance at this time was $56 \mathrm{ml}$./min. Six days later (4 November) this too had had no effect, but in vitro the minimum inhibitory concentrations of antibiotics for the organism had been established, i.e. for cephaloridine, $12.5 \mu \mathrm{g} . / \mathrm{ml}$., streptomycin, $12.0 \mu \mathrm{g} . / \mathrm{ml}$., and kanamycin, $12.5 \mu \mathrm{g} . / \mathrm{ml}$. Streptomycin treatment was, therefore, changed to kanamycin $0.5 \mathrm{~g}$. b.d. and cephaloridine $0.5 \mathrm{~g}$. every four hours intravenously. Two days later an embolus lodged in the right popliteal artery, requiring Rheomacrodex and heparin. Nevertheless, the signs gradually improved; the persistent pyrexia gave way to evening spikes of about $37.5^{\circ} \mathrm{C}$. On 25 November she had a rigor and two days later another rigor when the temperature rose to $40^{\circ} \mathrm{C}$. Serum taken four hours after the last dose of cephaloridine and kanamycin only partially inhibited the Esch. coli originally isolated from the blood.

Blood cultures taken during the rigors again grew Esch. coli despite the prolonged treatment with antibiotics. The minimum inhibitory concentrations of the organism were as follows: colistin, 3.125 $\mu \mathrm{g} . / \mathrm{ml}$., kanamycin, $12.5 \mu \mathrm{g} . / \mathrm{ml}$., cephaloridine, $6.25 \mu \mathrm{g} . / \mathrm{ml}$., cephaloridine and colistin combined, $3.125 \mu \mathrm{g} . / \mathrm{ml}$. each.

These results became available on I December when treatment was changed to cephaloridine I. $\circ \mathrm{g}$. intramuscularly every 4 hours and colistin one mega unit every 8 hours, but 2 days later pain developed in the left hypochondrium, the erythrocyte sedimentation rate rose to 138 , and 8 days later spikes of high temperature reappeared. The minimum inhibitory concentrations for the organism isolated from the blood on 25 November were now measured for trimethoprim and sulphamethoxazole; they were as follows: $0.3 \mu \mathrm{g} . / \mathrm{ml}$. and $10 \mu \mathrm{g} . / \mathrm{ml}$., respectively, when tested separately, and $0.05 \mu \mathrm{g} . / \mathrm{ml}$. and $\mathrm{r} \cdot 0 \mu \mathrm{g} . / \mathrm{ml}$. in combination. This was considered as good evidence of synergy, so treatment with tablets of the combination was added on 12 December and built up to a full dose of two tablets twice daily on I4 December. Each tablet contained 125 mg. trimethoprim and $250 \mathrm{mg}$. sulphamethoxazole.

At about this time a tachycardia reaching 160 was observed, and digitalis was prescribed on I6 December. Two days later malaise led to nausea and thence to vomiting for which perphenazine was prescribed. However, on 18 December jaundice was recognized, so cephaloridine and colistin were discontinued. Serum bilirubin was $1.8 \mathrm{mg} . / 100 \mathrm{ml}$. and rose to 4.3 mg./100 ml. two days later. Serum alkaline phosphatase was 92 King Armstrong units and rose to 127 within 2 days. The serum turbidity tests likewise rose. The serum aspartate transaminase rose to 90 units. The possibility of hepatotoxicity from trimethoprim and sulphamethoxazole was considered, but the patient had also received since admission promazine, chlorpromazine, phenylbutazone, nitrazepam, and several antibiotics. As the therapeutic choice for the underlying endocarditis was so limited, treatment with trimethoprim and sulphamethoxazole was continued. There were no further spikes of abnormal temperature and no further positive blood cultures. The jaundice subsided slowly. On II January I968 a liver biopsy revealed two distinct lesions. The first was one of small loci of reticulin collapse associated with chronic inflammatory cells and consistent with focal embolism of subacute bacterial endocarditis and the progressive abnormalities in liver function tests which had been noted since admission. The second lesion was one of marked cholestasis with many bile thrombi, proliferation of bile-ducts, and a cellular infiltrate consisting mainly of lymphocytes. It strongly suggested drug-induced intrahepatic cholestasis.

On 7 January commercial supplies of the drug combination became available as tablets containing $80 \mathrm{mg}$. trimethoprim and $400 \mathrm{mg}$. sulphamethoxazole ('Septrin'). ${ }^{1}$ The number of tablets prescribed was, therefore, increased to maintain a similar daily dose of trimethoprim. Three tablets were given twice daily, i.e. a total daily dose of $480 \mathrm{mg}$. trimethoprim and $2.4 \mathrm{~g}$. sulphamethoxazole. The patient continued to improve, in that her weight which was $57.3 \mathrm{~kg}$. on admission and $48.9 \mathrm{~kg}$. at the beginning of treatment with trimethoprim and sulphamethoxazole slowly increased, the liver function tests returned to normal values, and the haemoglobin rose to II.3 g./1000 ml. The erythrocyte sedimentation rate, however, remained high and was still II5 $\mathrm{mm}$. in the first hour at the time she was discharged from the ward on I5 February. No other cause for the high sedimentation rate was found; in particular there was no evidence of a collagen disease or systemic lupus erythematosus. It was therefore attributed to subacute bacterial endocarditis and 'Septrin' tablets were continued in the same dose. When last seen in April 1969 she was well and had no symptoms. Her weight was $58 \mathrm{~kg}$. The sedimentation rate was $55 \mathrm{~mm}$. The tablets were discontinued in September 1968.

\section{Comment}

This is the first record of subacute bacterial endocarditis being treated with trimethoprim and sulphonamide. The question arises how long should treatment be continued. Two early case reports of the successful treatment of proteus septicaemia (Noall, Sewards, and Waterworth, I962; Cooper and Wald, 1964) were encouraging. In both cases trimethoprim was used in combination with a triple sulphonamide and polymyxin, and the combination of all three different drug species was thought necessary for a bactericidal effect. In a further, equally desperate case of septicaemia due to Esch. coli, Darrell, Garrod, and Waterworth (I968) described a

1 This combination was simultaneously marketed as 'Bactrim' by Roche Products Ltd. 
cure without addition of polymyxin. In the present case, the correction of the anaemia, the gain in weight, and the positive feeling of wellbeing all suggest the cessation of septic emboli. The time relations leave little room for doubt that trimethoprim and sulphamethoxazole were responsible for these improvements.

A bactericidal effect of the combination is quite likely and should produce a cure, but serum concentrations required to achieve it are unknown. The minimum inhibitory concentrations reported by the laboratory assist in the choice of a suitable antibacterial regimen but do not help to decide the serum level to be maintained. This must be adequate to allow penetration of the vegetations for cure to be permanent. At the most anxious stage of the illness serum levels of trimethoprim and sulphamethoxazole were not measured. She was receiving $500 \mathrm{mg}$. trimethoprim and $\mathrm{I} \cdot \mathrm{O}$ g. sulphamethoxazole daily. Later when she was receiving $480 \mathrm{mg}$. trimethoprim and $2.4 \mathrm{~g}$. sulphamethoxazole daily the serum levels were: trimethoprim $3.2 \mu \mathrm{g} . / \mathrm{ml}$. and sulphamethoxazole 130.6 $\mu \mathrm{g} . / \mathrm{ml}$. three hours after a dose of two tablets of 'Septrin'. These levels would be close to peak values, and serum levels just before the tablets would be in the region of 2.0 $\mu \mathrm{g} . / \mathrm{ml}$. trimethoprim and $100 \mu \mathrm{g} . / \mathrm{ml}$. sulphamethoxazole. Had serum levels been available when the tablets with a lower proportion of sulphamethoxazole and a correspondingly higher proportion of trimethoprim were prescribed, higher doses would no doubt have been urged. For many patients including those whose cases are cited above have received higher doses of trimethoprim. However, when the serum levels became known to us we had begun to use the commercially available preparation with a higher proportion of sulphamethoxazole. Bearing in mind the low creatinine clearance recorded at the time of starting treatment with trimethoprim/sulphamethoxazole, a prolonged course rather than a concentrated course seemed prudent.

The onset of cholestatic hepatitis in this case shortly after the start of treatment with trimethoprim/sulphamethoxazole, and the necessity of persevering with the treatment, convinced us subsequently that the drug had no special dangers to a malfunctioning liver, even when other drugs given simultaneously had caused damage. A few case reports have appeared of sulphamethoxazole causing a sensitivity hepatitis (Fries and Siraganian, 1966; Dujovne, Chan, and Zimmerman, 1967), but the improvement which occurred while treatment continued excluded that diagnosis before even a biopsy could be taken. Despite the duration of therapy, theoretically capable of modifying folate metabolism, anaemia due to a severe infection process recovered without any specific treatment and without supplements of folate or folinate. The treatment was not, therefore, toxic to the patient.

\section{References}

Cooper, R. G., and Wald, M. (1964). Successful treatment of proteus septicaemia with a new drug, trimethoprim. Medical fournal of Australia, 2, 93.

Darrell, J. H., Garrod, L. P., and Waterworth, P. M. (1968). Trimethoprim: laboratory and clinical studies. Fournal of Clinical Pathology, 21, 202.

Dujovne, C. A., Chan, C. H., and Zimmerman, H. J. (1967). Sulfonamide hepatic injury. Review of the literature and report of a case due to sulfamethoxazole. New England Fournal of Medicine, 277, 785 .

Fries, J., and Siraganian, R. (I966). Sulfonamide hepatitis. Report of a case due to sulfamethoxazole and sulfisoxazole. New England fournal of Medicine, 274, 95 .

Noall, E. W. P., Sewards, H. F. G., and Waterworth, P. M. (1962). Successful treatment of a case of Proteus septicaemia. British Medical fournal, 2, IIOI. 